\title{
Copper distribution in leaves and roots of plants growing on a copper mine-tailing storage facility in northern Chile
}

\author{
Distribución de cobre en hojas y raíces de plantas que crecen sobre relaves mineros de \\ cobre en el norte de Chile
}

CLAUDIA ORTIZ-CALDERÓN ${ }^{1 *}$, ÓSCAR ALCAIDE ${ }^{1} \&$ JULIA LI KAO $^{2}$

\footnotetext{
${ }^{1}$ Departamento de Biología, Universidad de Santiago de Chile, Avenida Bernardo O’Higgins 3363, Santiago, Chile

${ }^{2}$ Departamento de Química y Biología, Universidad de Atacama, Avenida Copayapu 485, Copiapó, Chile * e-mail for correspondence: cortiz@usach.cl
}

\begin{abstract}
In a copper mine-tailing afforested we characterized the physicochemical properties of the substrate at vegetated and non-vegetated patches. We studied the accumulation of copper in roots and leaves of the species present at the site, to evaluate their phytoextraction and/or phytostabilization potential. The nonvegetated mine-tailing substrate showed a high content of metals, mainly copper $\left(>2.5 \mathrm{~g} \mathrm{~kg}^{-1}\right)$, a pH 7.4 , high content of salts and $5.0 \%$ organic matter. Vegetated patches at the tailing showed similar characteristics of $\mathrm{pH}$, salts and organic matter content, and showed a total copper concentration lower than the content found at the non-vegetated patches. Nine plant species present at the site were screened for copper accumulation and distribution in roots and leaves, and potential for copper phytoextraction or phytostabilization was suggested. The native species Schinus polygamus and Atriplex deserticola, accumulated over $1.2 \mathrm{~g} \mathrm{~kg}^{-1}$ copper in their leaves, showing that they are pseudometallophytes for the metal. Five of the nine plant species studied were considered suitable for phytoextraction procedures and four were apt for phytostabilization of copper polluted sites. By making a screening of species growing on a copper polluted site, we were able to select plants adapted to semi-arid environmental conditions and suitable for mine-tailings remediation purposes.
\end{abstract}

Key words: copper, phytoextraction, phytostabilisation, remediation, native plants.

\section{RESUMEN}

En un tranque de relaves previamente forestado, se realizó una caracterización fisicoquímica del sustrato en sectores vegetados y no vegetados. Se estudió la acumulación de cobre en raíces y hojas de las especies presentes en el sitio de trabajo, con el objeto de evaluar su potencial fitoextractor y fitoestabilizador. El sustrato del sector no vegetado presentó un $\mathrm{pH}$ 7,4; altos contenidos de sales y 5,0\% de materia orgánica, además de un alto contenido de metales pesados, principalmente cobre $\left(>2,5 \mathrm{~g} \mathrm{~kg}^{-1}\right)$. Los sectores vegetados del tranque de relaves presentaron características similares en cuanto a $\mathrm{pH}$, sales y contenido de materia orgánica, pero tenían concentraciones de cobre menores a las determinadas en los sectores no vegetados. Nueve especies presentes en el sitio fueron analizadas para determinar la acumulación de cobre en raíces y en hojas, y se sugirió la capacidad fitoextractora o fitoestabilizadora de cada especie. Las especies endémicas Schinus polygamus y Atriplex deserticola acumularon sobre $1,2 \mathrm{~g} \mathrm{~kg}^{-1}$ de cobre en sus hojas, presentando características de seudometalófitas para el metal. Cinco de las nueve especies estudiadas fueron consideradas adecuadas para procedimientos de fitoextracción de cobre, y cuatro especies mostraron capacidad para fitoestabilizar suelos contaminados con cobre. Mediante la identificación de especies que crecen sobre un sitio contaminado con cobre, fue posible seleccionar plantas adaptadas a ambientes semiáridos y adecuadas para ser utilizadas en programas de remediación de tranques de relaves.

Palabras clave: cobre, fitoextracción, fitoestabilización, remediación, plantas nativas.

\section{INTRODUCTION}

Copper is one of the most widely spread mineral resources on the earth's crust. In the north of Chile, soils are rich in metals, and copper is one of the most abundant components (Gonzalez et al. 1999). Chile has traditionally been dependent on copper exports; the stateowned company CODELCO is the world's largest copper-producing company, and foreign 
private investment has developed many new mines. It has been estimated that copper production in Chile will grow approximately 30 $\%$ by the year 2012 , contributing strongly to the country's economic development (Pérez 2006). However, copper extraction is an activity that has environmental impacts generated by the accumulation of wastes. The wastes are deposited in mine tailings made of fine particles generated after the extraction process. Mine tailings that are found in arid and semiarid regions where evaporation is high cause pollution by wind erosion, and the dust blown from the tailings has a high metal and metalloid content. If the mine wastes are not properly disposed of, there is a risk of spillage, seepage or landslides. Furthermore, the mine tailings and excavations have visual impacts on the environment (Miller 1999). A survey carried out by the Servicio Nacional de Geología y Minería (National Geology and Mining Service) (Sernageomin), recorded that more than $50 \%$ of 665 mine tailings in Chile have no recovery plans and are subsequently abandoned (Sernageomin 2003). At present a specific regulation for abandoned mine sites is being discussed by the Chilean government, but no laws for recovering abandoned mine sites or to regulate the stability of the tailings have been approved.

During the last decade, phytoremediation, a technology that uses plants to remove, stabilize, or detoxify pollutants, has provided an effective and in situ alternative method to remediate contaminated soils (Baker et al. 1994르, Blaylock 1997²). Under field conditions, there are several successful experiments in the phytostabilization metal-contaminated soils (Berti \& Cunningham 2000). It is reported that phytoremediation not only reduces the environmental risk of soil metal contamination, but also increases the activity and diversity of

BAKER AJM, SP MCGRATH, CMD SIDOLI \& RD REEVES (1994) The possibility of in situ heavy metal decontamination of polluted soils using crops of metal-accumulating plants. Environmental Biotechnology in Waste Treatment \& Recycle International Conference, Hong Kong. Resource Conservation Recycle 11: 41-49.

2 BLAYLOCK MJ (1997) Phytoremediation of lead contaminated soil at a brownfield site in New Jersey A cost effective alternative. IBC's Second Annual Conference on Phytoremediation, June 18-19, 1997, Seattle, Washington, USA. soil micro organisms and improves soil quality (Giller et al. 1998, Filip 2002). Successful phytoremediation depends on several factors; one of them is choosing the appropriate plant species that will be used in the remediation process (Marmiroli \& McCutcheon 2003). This selection should be supported by the knowledge of metal-tolerant plant species capable of growing on toxic soils, and adapted to saline and normally acid substrates (Ginocchio \& Baker 2004). Plants have the capability to rapidly adapt to their environment and evolve specific metal tolerance (Al-Hiyaly et al. 1990). In fact, most of the identified species that accumulate lead, cadmium, chromium, nickel, cobalt, copper, zinc, and selenium grow in sites with high metal content (Reeves \& Baker 2000). Therefore, it is worthwhile to evaluate the potential for phytoremediation of plants that normally grow in sites with high metal content in order to make a primary selection of those that are suitable for tailings reclamation purposes.

Planta Matta is a copper processing plant located in the Third Region of Chile. It belongs to ENAMI, where flotation wastes have been accumulating for more than 20 years. The wastes have generated two tailings deposits that cover an area of approximately $1,000 \mathrm{~m}^{2}$ to a height of $3 \mathrm{~m}$ with copper contents greater than $0.02 \%$ (ENAMI 2005). A tree planting plan on one of the tailings deposits was undertaken in 1988 in order to stabilize the surface and reduce wind erosion. The first stage of the planting plan was implemented on a $250 \mathrm{~m}^{2}$ area with six tree species: Acacia cyanophyla, Schinus polygamus, Casuarina equisetifolia, Acacia melanoxylon, Cupressus macrocarpa, and Prosopis chilensis. Young plants were planted using a random block design repeated three times. All the species used for the test were represented at least once in every block. The species were planted in a $30 \times 30 \times 30 \mathrm{~cm}$ grid at a distance of $2 \mathrm{~m}$ from one another. No additional materials were incorporated to the substrate, other than the soils in which the plants had been germinated and grown in the greenhouse.

In this study, we evaluate the results of the experiment with the following objectives: (1) to report plant species that survived and grew at the site; (2) to chemically characterize the soil of the tailings in vegetated and no vegetated 
sectors; and (3) to determine copper concentration in the roots and leaves of plants growing in copper-polluted soils. We also discuss the appropriateness of using plant species to vegetate copper-polluted sites in an arid environment, and the potential for copper phytoextraction and phytostabilisation of plant species that grow in a copper-polluted site.

\section{MATERIAL AND METHODS}

\section{Study site}

The Planta Matta copper processing plant is located in the Third Region of Chile $\left(27.3^{\circ} \mathrm{S}\right.$, $\left.70.3^{\circ} \mathrm{W}\right)$, which has a desert climate with average temperatures of $19{ }^{\circ} \mathrm{C}$ in springsummer and $14{ }^{\circ} \mathrm{C}$ in autumn-winter. Average annual rainfall is $20 \mathrm{~mm}$, all of it in winter (Inzunza 2004). Average wind speed in springsummer varies between 3.0 and $4.0 \mathrm{~m} \mathrm{~s}^{-1}$, and wind direction has a westerly (W) component. In autumn-winter the average wind velocity varies between 2.0 and $3.0 \mathrm{~m} \mathrm{~s}^{-1}$, and wind direction is $\mathrm{SW}$ to $\mathrm{SE}$. The processing plant is 1 $\mathrm{km}$ from the Paipote Copper Refinery and 8.0 $\mathrm{km}$ from the city of Copiapó (Fig. 1).

\section{Substrate analyses}

Substrate samples were collected where plants were growing (vegetated substrate) and from no vegetated sectors (no vegetated substrate). Also, control soil samples were taken from a no polluted and no vegetated site $1 \mathrm{~km}$ from the tailings deposit. Sampling of the vegetated substrate was randomized using grids were each plant was numbered. Substrate samples were collected every three plants over an area of approximately $50 \mathrm{~m}^{2}$. No vegetated substrate samples were taken from the same site in patches where no plants were growing. All the samples were taken from top to bottom at depth of $0-10 \mathrm{~cm}$ and $10-20 \mathrm{~cm}$ (fresh weight of approximately $1.5 \mathrm{~kg}$ ). Roughly $20 \mathrm{~g}$ of samples were oven-dried overnight at $40{ }^{\circ} \mathrm{C}$, homogenized, and sifted to a particle size of < $2.3 \mathrm{~mm}$. Plant residues were carefully removed and the samples were analyzed according to standardized methods used at the certified analysis laboratory of the Instituto de

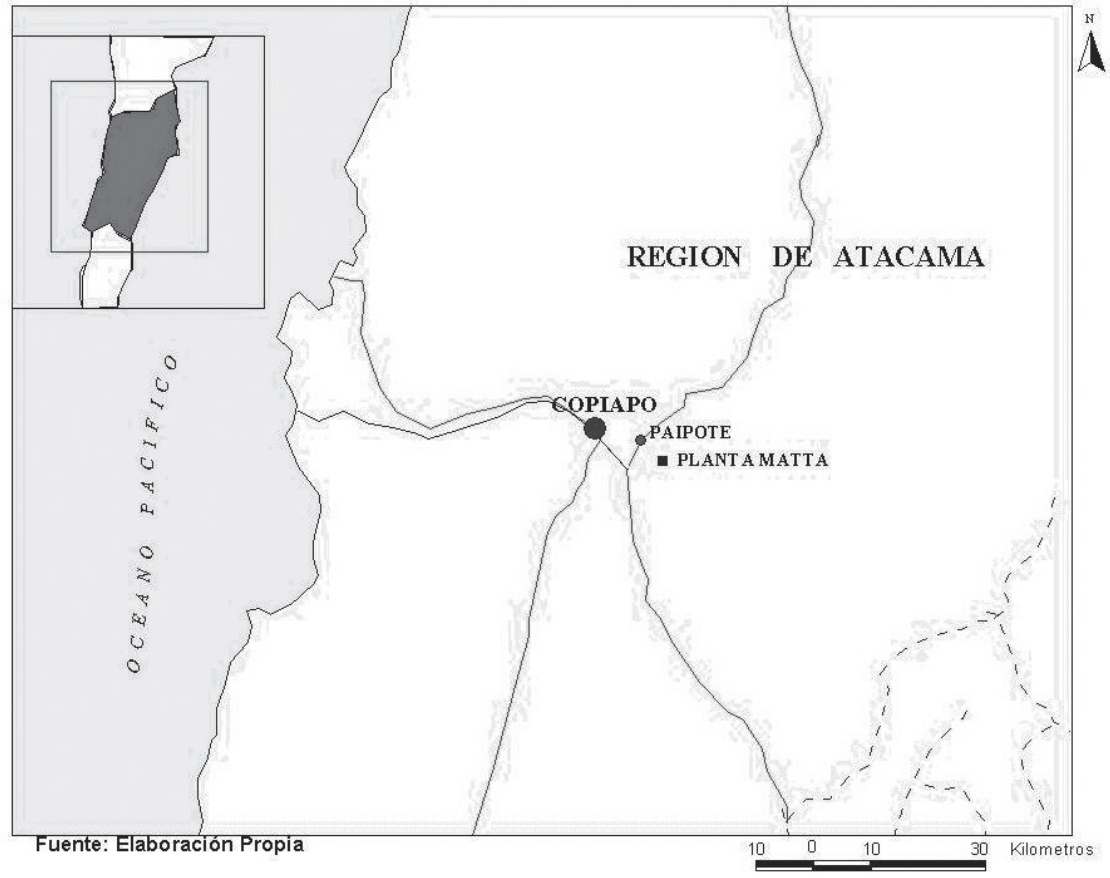

Fig 1: Map showing the location of the Planta Matta tailings deposit. The city of Copiapó is indicated.

Mapa de la ubicación del tranque de relaves de Planta Matta. Se indica la ciudad de Copiapó. 
Investigación Científica y Tecnológica of the Universidad de Atacama (IDICTEC). To determine total metal concentration, $1 \mathrm{~g}$ of sifted sample was digested in a microwave oven (Milestone, model Mega 1200), with $\mathrm{HNO}_{3}(70 \%)$ and $\mathrm{HF}(40 \%)$. After the digestion, the samples were cooled down, buffered with $\mathrm{H}_{3} \mathrm{BO}_{3}$, and filtered for further analysis (USEPA 1996). The concentrations of copper, arsenic, silver, lead and zinc were determined by flame atomic absorption spectrometry (AAS) (Perkin Elmer 3110 with FIAS-400 MHS-20 system). Mercury was determined using flow injection cold vapor generation coupled to AAS system (Boylan et al. 2001). The sample was dried and then thermally and chemically decomposed. The decomposition products were completely oxidized and the remaining decomposition products were carried to an amalgamator that selectively trapped mercury. After any remaining decomposition products were removed by oxygen, the amalgamator was rapidly heated, releasing mercury vapors. An oxygen flow carried the mercury vapors through absorbance cells positioned in the light path of the atomic absorption spectrophotometer (AAS). Total sulfur was determined by $\mathrm{BaCl}_{2}$ precipitation. The $\mathrm{pH}$ was measured in a $1: 2.5$ $\left(\mathrm{w} \mathrm{w}^{-1}\right)$ sample to deionized water mixture. Organic matter content was determined by the loss-on-ignition (LOI) method. A known weight of sample was placed in a ceramic container and heated at $440{ }^{\circ} \mathrm{C}$ overnight (ASTM, 2000). The sample's mass difference using the formula $\mathrm{OM}$ $(\%)=[(\mathrm{a}-\mathrm{b}) /(\mathrm{a}-\mathrm{c})] \times 100$, where, $\mathrm{a}=$ dry sample $(\mathrm{g})+$ container $(\mathrm{g})$; $\mathrm{b}=$ burnt residue $(\mathrm{g})+$ container $(\mathrm{g}) ; \mathrm{c}=$ container $(\mathrm{g})$. All weights were corrected for water content prior to the organic matter content calculation. Water content was measured as the ratio of the weight of water to the weight of the solids in a weighed mass of sample. The ratio was expressed as percentage of water. Extractable $\mathrm{P}$ was determined by the Olsen method, based on alkaline extraction by $0.5 \mathrm{~N} \mathrm{NaHCO}_{3}($ Olsen \& Sommers, 1982). Total reduced $\mathrm{N}$ was determined by the wet oxidation of soil using a micro Kjeldahl procedure with $\mathrm{H}_{2} \mathrm{SO}_{4}$ and digestion catalyst. Equilibrium extraction of exchangeable $\mathrm{K}$ was performed using $1 \mathrm{~N}$ $\mathrm{CH}_{3} \mathrm{COO}\left(\mathrm{NH}_{4}\right)(\mathrm{pH}$ 7.0) and subsequent determination by AAS (Perkin Elmer 3110).

\section{Plant analyses}

Samples of nine plant species found in the 250 $\mathrm{m}^{2}$ vegetated part of the tailings were collected. Some of the species collected were grasses that had colonized the site spontaneously. Five samples of each species were selected at random using grids at the sampling plot, where each plant was numbered. The individuals were collected every three numbered plants in the sampling plot over an area of approximately 50 $\mathrm{m}^{2}$. Plant samples were collected by digging out the root system as completely as possible, thereby collecting the whole plants, which were immediately transported to the laboratory and were weighed (fresh weight) and divided for analysis into roots and leaves. Both fractions were washed with a solution of phosphate-free detergent, then with dilute $\mathrm{HNO}_{3}$ solution (aqua regia), and finally with abundant deionized water. The samples were dried at $70{ }^{\circ} \mathrm{C}$ and ground to pass through a $500 \mu \mathrm{m}$ stainless steel sieve. The material was then crushed and a 1.0$\mathrm{g}$ representative sample was digested in $65 \%$ $\mathrm{HNO}_{3}$ and $35 \% \mathrm{H}_{2} \mathrm{O}_{2}$ for 15 min using a Milestone ETHOS D microwave system. The samples were placed in suitably microwaveinert polymer vessels that were sealed and heated in the microwave system. The temperature profile was $180{ }^{\circ} \mathrm{C}$ for $2 \mathrm{~min}, 200$ ${ }^{\circ} \mathrm{C}$ for $11 \mathrm{~min}$, and $210{ }^{\circ} \mathrm{C}$ for $5 \mathrm{~min}$. After cooling, the vessels' contents were filtered through $0.2 \mu \mathrm{m}$ membranes (Schleicher \& Schuell MicroScience), and then analyzed for total copper content using AAS (Perkin Elmer 3110 with FIAS-400 MHS-20 system). A standard reference material with a certified copper content of $439 \pm 22 \mathrm{mg} \mathrm{kg}^{-1}$ was used (TORT-1, National Research Council of Canada; lobster hepatopancreas; kindly provided by Universidad de Talca).

\section{Statistical methods}

Analysis of variance (ANOVA) was used for testing the copper content differences in the substrates and plant tissues. A significance level of $\mathrm{P}<0.05$ was used for the study. We used the Tukey honest significant difference as the posteriori test $(\alpha=0.05)$. Statistical analyses were performed with Analyse-it Statistical Software (Analyse-it for Microsoft Excel, Leeds, United Kingdom: http://www .analyse-it.com/) 
RESULTS

\section{Substrate analyses}

The substrate at the vegetated site had a neutral $\mathrm{pH}$, low organic matter content, and high sulfur content (Table 1). The physicochemical parameters of the vegetated plots showed no significant differences in organic matter content and $\mathrm{pH}$ between the analyzed samples (vegetated, non-vegetated, and control) (Table 1). On the contrary, water content was significantly higher in samples where plants grew, compared to control soil. Both conductivity and salinity of the samples taken from the vegetated plot were lower than in the control soil. The non-vegetated substrate was composed of fine particulate matter and had a neutral $\mathrm{pH}$, low organic matter content, and a high level of metals; mainly copper (Table 2).
When metal content in substrate samples was analyzed, we found that the copper, arsenic, and zinc content in the vegetated plot were significantly different for samples taken at different depths (Table 2). The metal content where most of the root tissue was found (0-10 $\mathrm{cm}$ depth) was similar to the amounts found in the control soil (Table 2). Total Fe content showed significantly higher values in the vegetated samples compared to the control soil, but $\mathrm{Fe}$ concentration was similar in the vegetated and no vegetated samples taken from the tailing deposit (Table 2). Phosphorus content $\left(\mathrm{mg} \mathrm{kg}^{-1}\right)$ of the vegetated substrate at a depth of $0-10 \mathrm{~cm}$ was higher $\left(5 \pm 0.6 \mathrm{mg} \mathrm{kg}^{-1}\right)$ than at a depth of $10-20 \mathrm{~cm}(<4)$. Nitrogen content neat the surface $(0-10 \mathrm{~cm})$ in the vegetated site was $124 \pm 5.5 \mathrm{mg} \mathrm{kg}^{-1}$, higher than the content found at $10-20 \mathrm{~cm}(70 \pm 6.1$ $\left.\mathrm{mg} \mathrm{kg}^{-1}\right)$. Non-significant differences were

TABLE 1

Physicochemical characterization of the vegetated substrate. Samples were taken at depths of 0-10 $\mathrm{cm}$ and $10-20 \mathrm{~cm}$

Caracterización fisicoquímica del sustrato vegetado. Las muestras se tomaron a una profundidad de 0-10 cm., y 10-20 cm

\begin{tabular}{lcccccc}
\hline Substrates & Organic matter(\%) & $\mathrm{pH}$ & $\begin{array}{c}\text { Conductivity } \\
\left(\mathrm{mS} \mathrm{cm}^{-1}\right)\end{array}$ & Salinity $\left(\mathrm{mg} \mathrm{L}^{-1}\right)$ & Total S(\%) & Moisture(\%) \\
\hline Vegetated tailings $(0-10 \mathrm{~cm})$ & $5.2 \pm 1.1$ & 7.4 & $1.9^{\mathrm{a}}$ & $1241^{\mathrm{a}}$ & $0.6^{\mathrm{a}}$ & $10.3^{\mathrm{a}}$ \\
Vegetated tailings $(10-20 \mathrm{~cm})$ & $4.7 \pm 0.8$ & 7.5 & $1.4^{\mathrm{a}}$ & $889^{\mathrm{b}}$ & $1.0^{\mathrm{b}}$ & $10.5^{\mathrm{a}}$ \\
Non-vegetated tailings & $5.1 \pm 0.8$ & 7.4 & N.D. & N.D. & N.D. & N.D. \\
Controlsoil & $5.9 \pm 1.3$ & 7.4 & $5.7^{\mathrm{b}}$ & $3622^{\mathrm{c}}$ & $0.6^{\mathrm{a}}$ & $2.3^{\mathrm{b}}$ \\
\hline
\end{tabular}

Different letters represent differences between the samples; ND = not determined; mean \pm SE for five samples are shown

TABLE 2

Total elements content of substrate samples taken from the studied site. Control samples were taken at a depth of $20 \mathrm{~cm}$

Contenido total de elementos en muestras de sustrato no vegetado y suelo control. Las muestras control fueron tomadas a $20 \mathrm{~cm}$. de profundidad

\begin{tabular}{lcccc}
\hline Element $\left(\mathrm{mg} \mathrm{kg}^{-1}\right)$ & \multicolumn{3}{c}{ Sample type } \\
\cline { 2 - 5 } & Control soil & No vegetated substrate & $\begin{array}{c}\text { Vegetated substrat } \\
(0-10 \mathrm{~cm} \mathrm{depth})\end{array}$ & $\begin{array}{c}\text { Vegetated substrate } \\
(10-20 \mathrm{~cm} \mathrm{depth})\end{array}$ \\
\hline $\mathrm{Cu}$ & $70 \pm 1.8^{\mathrm{a}}$ & $2550 \pm 50^{\mathrm{b}}$ & $60 \pm 3.1^{\mathrm{a}}$ & $290 \pm 3.8^{\mathrm{c}}$ \\
$\mathrm{Zn}$ & $131 \pm 9^{\mathrm{a}}$ & $210 \pm 78^{\mathrm{a}}$ & $116 \pm 3.2^{\mathrm{a}}$ & $216 \pm 5^{\mathrm{a}}$ \\
$\mathrm{K}$ & $46 \pm 1.5^{\mathrm{a}}$ & $55 \pm 9^{\mathrm{a}}$ & $25 \pm 2.1^{\mathrm{b}}$ & $21 \pm 0.8^{\mathrm{b}}$ \\
$\mathrm{As}$ & $70 \pm 5^{\mathrm{a}}$ & $75 \pm 7.2^{\mathrm{a}}$ & $74 \pm 2.2^{\mathrm{a}}$ & $136 \pm 3.5^{\mathrm{b}}$ \\
$\mathrm{Fe}$ & $0.036^{\mathrm{a}}$ & $1244 \pm 20^{\mathrm{b}}$ & $0.174^{\mathrm{c}}$ & $0.123^{\mathrm{c}}$ \\
\hline
\end{tabular}

Different letters represent differences between samples; means \pm SE for five samples are shown 
found for the nitrogen content at the control site $\left(182 \pm 6.6 \mathrm{mg} \mathrm{kg}^{-1}\right)$. In the samples taken from the vegetated sectors of the tailings deposit at a depth of $0-10 \mathrm{~cm}$ and $10-20 \mathrm{~cm}$ there were significant differences in $\mathrm{N}, \mathrm{P}$, salinity, $\mathrm{S}, \mathrm{Cu}, \mathrm{As}$, and $\mathrm{Zn}$ levels depending on the depth from which the samples were taken (Table 1 and Table 2). Contents of $\mathrm{Hg}, \mathrm{Ag}, \mathrm{Pb}$ and $\mathrm{Se}$ were also determined in the no vegetated site. $\mathrm{Hg}$ content was $0.5 \mathrm{mg} \mathrm{kg}^{-1}, \mathrm{Ag}$ content was $2.4 \pm 0.3 \mathrm{mg} \mathrm{kg}^{-1}, \mathrm{~Pb}$ content was $34 \pm 2.7 \mathrm{mg} \mathrm{kg}^{-1}$, and Se was $6 \pm 1.3 \mathrm{mg} \mathrm{kg}^{-1}$.

\section{Copper content in plants}

Nine vascular plant species were recorded in an area of $250 \mathrm{~m}^{2}$. Five of the species were identified as native: Baccharis salicifolia, Schinus polygamus, Atriplex deserticola, Scirpus asper, and Polypogon australis; and four were identified as non-native species: Casuarina equisetifolia, Acacia melanoxylon, Pennisetum clandestinum, and Cynodon dactylon. Young and adult plants of the nine species were present, of which four grasses were found under the tree canopy. Atriplex deserticola plants were found on the slope of the tailings deposit.

Since copper was the most abundant metal present at the site, the level of this element was determined in 1.0 to $2.0 \mathrm{~g}$ (fresh weight) of leaves and roots of the nine species mentioned (Table 3). Copper accumulated both in the leaves and the roots of all the species in a species-dependent way. The amount of copper in leaves and roots in $\mathrm{mg} \mathrm{kg}^{-1}$ of dry plant weight was used to calculate a leaves: roots (L:R) copper ratio. Copper content in stems was not determined. The $\mathrm{L}: \mathrm{R}$ ratio ranged between 0.2 ( $C$. equisetifolia) to 9.4 ( $B$. salicifolia). Five species ( $S$. polygamus, $B$. salicifolia, $S$. asper, $C$. dactylon, and $P$. australis) showed an L: $\mathrm{R}>1.0$, indicating copper movement from roots to shoots. Casuarina equisetifolia, A. melanoxylon, A. deserticola, and $P$. clandestinum had an L: $\mathrm{R}<$ 1.0 , accumulating more copper in the roots than in the leaves (Table 3).

Three of the species found at the study site belonged to the Poaceae family (Table 3 ). $S$. polygamus and $A$. deserticola accumulated more than $1000 \mathrm{mg} \mathrm{kg}^{-1}$ of copper in their leaves. A. deserticola was particularly interesting because the plants found grew on the slope of the tailings deposit and had an abundant foliar mass. Casuarina equisetifolia, A. deserticola, A. melanoxylon, and $P$. clandestinum accumulated 1.6 to 6.0 times more copper in the roots than in the leaves (Table 3). In the present study the largest amount of root copper concentration was found in C. equisetifolia, which accumulated $2.9 \mathrm{~g}$ of $\mathrm{Cu}$ per kg dry weight.

The amount of copper found in the leaves of all the species was higher than $100 \mathrm{mg} \mathrm{kg}^{-1}$ of dry matter. A more detailed analysis indicated

TABLE 3

Copper content in leaves and roots of plants collected from the tailings deposit

Contenido de cobre en hojas y raíces de plantas colectadas en el tranque de relaves

\begin{tabular}{|c|c|c|c|c|}
\hline \multirow[t]{2}{*}{ Plant species } & \multicolumn{2}{|c|}{ Copper content ( $\mathrm{mg} \mathrm{kg}^{-1}$ dry wt) } & \multirow{2}{*}{$\begin{array}{l}\text { Leaves + roots copper } \\
\quad\left(\mathrm{mg} \mathrm{kg}^{-1} \text { dry wt }\right)\end{array}$} & \multirow{2}{*}{$\begin{array}{l}\text { Leaves:roots } \\
\text { ratio(L:R) }\end{array}$} \\
\hline & Leaves & Roots & & \\
\hline Baccharis salicifolia (PWS, As) & $667.9 \pm 2.4$ & $71.3 \pm 0.4$ & 739.2 & 9.4 \\
\hline Schinus polygamus $(\mathrm{P}, \mathrm{Ana})$ & $1,213.5 \pm 8.9$ & $260 \pm 0.9$ & $1,473.5$ & 4.7 \\
\hline Casuarina equisetifolia $(\mathrm{P}, \mathrm{Ca})$ & $470.2 \pm 3.3$ & $2,923.3 \pm 7.7$ & $3,393.5$ & 0.2 \\
\hline Atriplex deserticota(PWS, Che) & $1,357.7 \pm 3.5$ & $2160 \pm 71$ & $3,517.7$ & 0.6 \\
\hline Acacia melanoxylon $(\mathrm{P}, \mathrm{Le})$ & $158.6 \pm 1.6$ & $484.0 \pm 8.9$ & 642.6 & 0.3 \\
\hline Pennisetum clandestinum $(\mathrm{G}, \mathrm{Po})$ & $259.2 \pm 6.2$ & $866.4 \pm 7.1$ & $1,125.6$ & 0.3 \\
\hline Scirpus asper $(\mathrm{G}, \mathrm{Cy})$ & $459.3 \pm 5.0$ & $250.7 \pm 6.1$ & 710 & 1.8 \\
\hline Cynodon dactylon $(\mathrm{G}, \mathrm{Po})$ & $246.5 \pm 8.1$ & $81.4 \pm 0.6$ & 327.9 & 3.0 \\
\hline Polypogon australis $(\mathrm{G}, \mathrm{Po})$ & $669.5 \pm 5.9$ & $223 \pm 16$ & 892.5 & 3.0 \\
\hline
\end{tabular}

P: perennial; PWS: persistent woody shoots; G: grass; Po: Poaceae; As: Asteraceae; Cy: Cyperaceae; Che: Chenopodiaceae; Ca: Casuarinaceae; Le: Leguminosaceae; Ana: Anacardiaceae; means \pm SE for five samples are shown 
that the largest copper content was found in the leaves of $S$. polygamus and A. deserticola, and the highest shoots-to-roots copper ratio, 9.4, was found in $B$. salicifolia. The grasses with the highest $\mathrm{L}: \mathrm{R}$ ratio, between 1.8 and 3.0, were S. asper, $C$. dactylon and $P$. australis (Table 3), suggesting a movement of copper from roots to leaves in the plants. On the contrary, $P$ clandestinum presented a shoots to roots ratio of less than 1.0 , indicating more copper accumulation in the roots than in the leaves.

\section{DISCUSSION}

Although a substrate derived from a minetailing is not considered a proper type of soil, zinc and iron content in the samples were similar to those reported for serpentine soils (Reeves \& Baker 2000). However, copper levels were much higher than expected for that type of soil, and potassium levels were about ten times lower than those reported for serpentine soils (Reeves \& Baker 2000). On the other hand, arsenic content was similar to that reported by Bleymard \& Bleiberg for lead/zinc type soils, except for the low lead level (Reeves $\&$ Baker 2000). Copper level in the samples was about 10 to 100 times higher than that found in soils used for agricultural purposes (Ginnocchio \& Narvaez 2002). However, the copper level in the polluted site was lower than that $\mathrm{n}$ found in soils used for metal extraction or in tailings deposits (Reeves \& Baker 2000). It might be possible that the presence of the plants had an effect on the availability of copper in the analyzed samples (Romkens et al. 1999).

The similar organic matter content in the three soil types analyzed may be due to a poor decomposition process and a low development of microbiota at the rhizosphere of the plants in the vegetated plot (Basta et al. 2005, Carrasco et al. 2006). The differences found in water content, conductivity, and salinity between the tailing area and the control area, where there has been no mining activity, may be due to the scarce vegetation found at the control site where the samples were taken, and the natural salinity of the soils in northern Chile (Celis \& Letelier 1999). Under the arid conditions of the area where the control sampling was done there is little vegetation compared to the higher plant density at the tailings site. Plant roots in the polluted site have root matrices that contribute to maintain the substrate with more moisture that in the control site, because of the hydraulic effect of the roots of woody species. The root matrix in the tailings area would make less available the salts at the site, affecting the conductivity of the substrate (Angers \& Caron 1998).

The bioavailability and solubility of metals in soils strongly depends on $\mathrm{pH}$, organic matter, and the type and quantity of minerals (Delgado \& Serey 2002). It has been shown that $\mathrm{pH}$ values below 5.5 may enhance $\mathrm{Cu}$ mobility, biological availability, and toxicity in soils (Martinez \& Motto 2000), while organic matter "traps" the metal, lowering its bioavailability (Römkens et al. 1999). Sulfur content found at the vegetated site might be related to soluble copper/sulfur complexes of the ore from which copper was extracted, which are commonly found in tailings (Allen \& Sheppard 1971, Macnair 1993). Although metal solubility in soil is a process that depends on several factors, as has been reported for Chilean soils by Ginocchio \& Narvaez (2002), at the studied site it may be possible that the low organic matter content and the soluble form of copper are more important factors than the $\mathrm{pH}$ of the soil samples for the mobility of the metal from the substrate matrix to the plants. However, chemical analyses need to be performed to demonstrate this observation. The high copper levels found in the tissues of plant species growing at the site was an indication of the metal's mobility, and the distribution of $\mathrm{Cu}$ in plant tissues was an indication that the uptake by plants was a process depending on the biochemical mechanisms of each species (Song et al. 2004).

Individuals of $A$. cyanophilla, $C$. macrocarpa and $P$. chilensis that were originally planted at the site were not found at the time of the study. It is believed that the level of copper in the soil was too high and/or the plants were exposed for a long enough period of time to the metal, so the protection mechanisms were overwhelmed and the plants died after a few years (Ginnocchio 2000). However, A. melanoxylon, C. equisetifolia and $S$. polygamus were still growing on the tailings, and some grass species had spontaneously 
colonized the site. It may be that the surviving species developed copper tolerance through cellular mechanisms already described in the literature but not studied in this work (Pollard at al. 2002). The plant strategies to cope with the copper present in the polluted site could be either to exclude the metal at the root or to take the element up and partition it among the leaves, stem, and roots, or a combination of both (Baker 1981, Pollard et al. 2002).

Although copper is essential for plant growth, when present in large amounts in soils it is generally phytotoxic and can cause the death of the plants (Rhoads et al. 1989). Numerical thresholds for the metal in soil above which phytotoxicity occurs have been suggested, ranging from 140 to $280 \mathrm{mg} \mathrm{kg}^{-1}$ of total copper (Neuman et al. 1987). For most crop species, the critical level for copper toxicity in leaves is above 20 to $30 \mathrm{mg} \mathrm{kg}^{-1}$ dry wt. (McBride \& Martinez 2000). Plants growing in soils with high metal concentrations due to human activities such as mining and smelting, behave as edaphic endemics (Kruckeberg \& Rabinowitz 1985, Kruckeberg 1986) or pseudometallophytes, which are species that have populations on both metalliferous and nonmetalliferous soils (Bert et al. 2000). This is in agreement with several studies showing that metal tolerance is an adaptive physiological trait that can produce local ecotypes on metal-polluted soils (Bush \& Barret 1993, Macnair et al. 1993). Plant species belonging to the Asteraceae, Cyperaceae and Poaceae families found at the polluted site (Table 3) showed copper content in leaves between 250 to $660 \mathrm{mg} \mathrm{kg}^{-1}$, which is 5.0 to 12.0 times lower than the amounts reported for copper hyperaccumulator species of the same families (Reeves \& Baker 2000). Schinus polygamus (Anacardiaceae) and A. deserticola (Chenopodiaceae) accumulated more than $1,000 \mathrm{mg} \mathrm{kg}^{-1}$ of copper in their leaves, so they might be considered as hyperaccumulator metallophytes according to the definition given by Malaise et al. (1978).

The amount of copper accumulated in the roots of $C$. equisetifolia, A. deserticola, A. melanoxylon, and $P$. clandestinum indicated that the four species have an extraordinary ability to take up copper from the polluted soils and to accumulate the metal in their roots, so they could be used to phytostabilize metal- polluted soils. In the present study the highest amount of copper in roots was found in $C$. equisetifolia, which accumulated $2.9 \mathrm{~g} \mathrm{~kg}^{-1} \mathrm{Cu}$, almost twice the amount of $\mathrm{t}$ metal found in tolerant copper-accumulators (Jiang et al 2004). This result might be related to the spreading, fibrous root system that the plant can develop in a short time, so it can penetrate quite deeply into the soil, favoring uptake of the element (Torrey \& Berg 1988).

The L: $\mathrm{R}$ ratios above 1.0 found in some of the species indicate a movement of the metal from the roots to the shoots, resulting in an accumulation of copper in the leaves, and a potential to extract copper from the site. This is particularly interesting for $S$. polygamus, A. deserticola, and $B$. salicifolia because the three species have been reported as deep-root plants adapted to arid environments (Gutiérrez et al. 2000). The ability of some plants to survive and reproduce while accumulating high concentrations of metals is a requirement when plants are used to immobilize metals present in polluted soils (Cai \& Ma 2003). The toxicity of metals that are to be removed by the plants is a limiting step for the use of phytotechnologies, as is the stress caused by environmental conditions in the north of Chile, where several tailings deposits are located. Plant species which are able to grow and reproduce under these harsh conditions are of particular interest to phytotechnologies.

Although the grasses S. asper, C. dactylon and $P$. australis do not have deep root systems, the movement of copper to the aerial part of the plants as deduced by the $S: R$ ratio found for them, makes them suitable for phytoextraction of the metal. Besides, the three species have a fast growth rate (Daehler 2003), so they can be harvested after a season of accumulation as has been suggested for $C$. dactylon (Madejon et al. 2002). However, the productivity of the species needs to be determined under field conditions to claim the proper use of the plants for phytoextraction purposes. The L: $\mathrm{R}$ ratio found for $P$ clandestinum indicated copper accumulation in the roots and a potential for phytostabilization of copper-polluted sites

Although copper content at the working plots was homogeneous (Table 2), the accumulation and tissue distribution of copper showed by the nine species screened was different and species-specific. It has been 
shown that even when there are common mechanisms to tolerate metals in plants, the uptake and tolerance threshold are dependent on the plant's genetics (Macnair 1979, Rajakaruna 2004). Although the mechanisms involved in the plant uptake of copper were not studied in this work, the high levels of the metal found in the leaves and roots of the studied plants might be the result of a slow translocation caused by constant exposure to the copper present in the soils (Salgado \& Serey 2002).

All the species showed desirable traits to phytoextract and/or phytostabilize copperpolluted soils, although only S. polygamus and A. deserticola can be considered as a pseudometallophytes for copper. If this condition has developed in these plants in the span of about 18 years, further investigation should be done, since it is generally believed that this process takes a much longer time than this. The endemic A. deserticola is adapted to the environmental conditions of the site, so the plants could grow and propagate easily. In a mine waste area located in an arid environment, phytostabilization of the tailings is more suitable than phytoextraction of the contaminant, due to the fact that cooper is present in high concentration and it is important to avoid the dispersion of contaminated dust. Phytoextraction is not efficient in an area where there is a large amount of contaminants (a too long time might be needed to "clean" the area), and there is always a risk of introducing copper into the food chain, if accumulator plants are consumed by animals. Taking this into account is very interesting to find autochthonous plants for stabilizing tailings due to the hard environmental conditions of Chile's northern regions. The pseudometallophyte species described could be very useful in cooper contaminated areas, yielding positive results in a cost/benefit analysis of this remedial action. We suggest using $S$. polygamus and $A$. deserticola for remediation of contaminated sites in arid and semi-arid regions of Chile. The two species are medium- to fast-growing plants which would favor soil stabilization. The use of a multispecific phytoremediation system has been recommended as an effective approach to clean and stabilize metal-polluted sites (Norman \& Raforth 1998, Lambert et al. 1999).
A variety of root systems provided by different plant species would stabilize the soil mimicking wind erosion and material slides, typically occurring in arid and semiarid regions (Smith at al. 1998, Baer et al. 2005).

\section{LITERATURE CITED}

AL-HIYALY S, T MCNEILLY \& AD BRADSHAW (1990) The effect of zinc contamination from electricity pylons. Contrasting patterns of evolution in five grass species. New Phytologist 114: 183-190.

ALLEN W \& P SHEPPARD (1971) Copper tolerance in some Californian populations of the monkey flower, Mimulus guttatus. Proceedings of the Royal Society of London 177: 177-196.

ANGERS DA \& J CARON (1998) Plant-induced changes in soil structure: Processes and feedbacks. Biogeochemistry 42: 55-72.

ASTM (2000) Standard test methods for moisture, ash, and organic matter of peat and other organic soils. American Society for Testing and Materials, West Conshohocken, Pennsylvania, USA. 2974-00

BAER SG, SL COLLINS, JM BLAIR, AK KNAPP \& AK FIEDLER (2005) Soil Heterogeneity effects on tallgrass prairie community heterogeneity: an application of ecological theory to restoration ecology. Restoration Ecology 13: 413-424.

BAKER A (1981) Accumulators and excluder-strategies in the response of plants to heavy metals. Journal of Plant Nutrition 3: 643-646.

BERT $\mathrm{V}$, MR MACNAIR, $P$ DELAGUERIE, $P$ SAUMITOU-LAPRADE \& D PETIT (2000) Zinc tolerance and accumulation in metallicolous and nonmetallicolous populations of Arabidopsis halleri (Brassicaceae). New Phytologist 146: 225-233.

BASTA NT, RYAN JA \& RL CHANEY (2005) Trace element chemistry in residual-treated soil: key concepts and metal bioavailability. Journal of Environmental Quality 34: 49-63.

BERTI WR \& SD CUNNINGHAM (2000) Phytostabilisation of metals. In: Raskin I \& B Ensley (eds) Phytoremediation of toxic metals: using plants to clean the environment: 6: 71-88. Editorial Wiley, New York, USA.

BOYLAN HM, RC RICHTER, HM KINGSTON \& A RICOTTA (2001) Rapid mercury analysis for the field: method development and application to natural gas utility sites. Water, Air, and Soil Pollution 127: 255-270.

BUSH EJ \& SCH BARRET (1993) Genetics of mine invasions by Deschampsia caespitosa (Poaceae). Canadian Journal of Botany 71: 1336-1348.

CAI Y \& L MA (2003) Metal tolerance, accumulation, and detoxification in plants with emphasis on arsenic in terrestrial plants. Proceedings of the American Chemical Society USA 8: 95-114.

CARRASCO L, CARAVACA F, ÁLVAREZ-ROGEL J \& A ROLDAN (2006) Microbial processes in the rhizosphere soil of a heavy metals-contaminated Mediterranean salt marsh: a facilitating role of AM fungi. Chemosphere 64: 104-111.

CELIS A \& E LETELIER (1999) Ruralidad, agricultura y sustentabilidad. En: Larraín \& Reyes (eds) Por un Chile sustentable, propuesta ciudadana para el cambio: 75-82. IEP-RENACE-U. Bolivariana, Santiago, Chile, 486 pp. 
DAEHLER CC (2003) Performance comparisons of cooccurring native and alien invasive plants: implications for conservation and restoration. Annual Review of Ecology and Systematics 34: 183-211.

DELGADO L \& I SEREY (2002) Copper distribution in Mediterranean forest ecosystems. Revista Chilena de Historia Natural 75: 557-565.

FILIP Z (2002) International approach to assessing soil quality by ecologically-related biological parameters. Agricultural Ecosystem \& Environment 88: $169-174$

GILLER KE, E WITTER \& SP MCGRATH (1998) Toxicity of heavy metals to microorganisms and microbial processes in agricultural soils: a review. Soil Biology and Biochemistry 30: 1389-1414.

GINOCCHIO R (2000) Effects of a copper smelter on a grassland community in the Puchuncaví Valley, Chile. Chemosphere 41: 15-23.

GINOCCHIO R \& J NARVÁEZ (2002) Importance of the chemical form and type of substrate for copper toxicity in Noticastrum sericeum (Less.) Less. ex Phil. Revista Chilena de Historia Natural 75: 603612.

GINOCCHIO R \& A BAKER (2004) Metalófitas en América Latina: un recurso biológico y genético único poco conocido y estudiado en la región. Revista Chilena de Historia Natural 77: 185-194.

GONZÁLEZ S (1994) Estado de la contaminación de los suelos en Chile. En: Espinoza G, P Pisani, L Contreras \& P Camus (eds) Perfil ambiental de Chile: 199-234. Comisión Nacional de Medio Ambiente, Santiago, Chile. 569 pp.

GUTIÉRREZ JR, G ARANCIO \& FM JAKSIC (2000) Variation in vegetation and seed bank in a Chilean semi-arid community affected by ENSO 1997. Journal of Vegetation Science 11: 641-648.

INZUNZA J (2000) Meteorología descriptiva y aplicaciones en Chile. Universidad de Concepción, Chile. http://www.udec.cl/ jinzunza/meteo/ cap1.pdf

JIANG LY, XE YANG \& ZL HE (2004) The growth response and phytoextraction of copper at different levels in soils by Elsholtzia splendens. Chemosphere 55: 1179-1187.

KRUCKEBERG AR (1986) An essay: the stimulus of unusual geologies for plant speciation. Systematic Botany 11: 455-463.

KRUCKEBERG AR \& D RABINOWITZ (1985) Biological aspects of rarity in higher plants. Annual Review of Ecology and Systematics 16: 447-479.

LAMBERT M, G PIERZYNSKI, G HETTIARACHCHI, LE ERICKSON \& D SWEENEY (1999) Revegetation of heavy metal-contaminated mine tailings (CHAT). Proceedings of the 1999 Conference on Hazardous Waste Research, 114120

MCBRIDE M \& CE MARTÍNEZ (2000) Copper phytotoxicity in a contaminated soil: remediation tests with adsorptive materials. Environmental Science Technology 34: 4386-4391.

MACNAIR MR (1979) The genetics of copper tolerance in the yellow monkey flower, Mimulus guttatus. I. Crosses to nontolerants. Genetics 91: 553-563.

MACNAIR M, S SMITH \& O CUMBES (1993) Heritability and distribution of variation in degree of copper tolerance in Mimulus guttatus at Copperopolis, California. Heredity 71: 445-455.

MADEJON P, JM MURILLO, T MARANÓN, F CABRERA \& R LÓPEZ (2002) Bioaccumulation of $\mathrm{As}, \mathrm{Cd}, \mathrm{Cu}, \mathrm{Fe}$ and $\mathrm{Pb}$ in wild grasses affected by the Aznalcóllar mine spill (SW Spain). Science of the Total Environment 290: 105-120.

MALAISSE F, J GRÉGOIRE, R BROOKS, R MORRISON \& R REEVES (1978) Aeollanthus biformifolius De Wild: a hyperaccumulator of copper from Zaïre. Science 199: 887-888.

MARMIROLI N \& MCCUTCHEON SC (2003) Phytoremediation: transformation and control of contaminants. In McCutcheon and Schnoor (eds) Making phytoremediation a successful technology: 85-119. John Wiley \& Sons, Inc., Hoboken, New Jersey, USA.

MARTINEZ C E \& HL MOTTO (2000) Solubility of lead, zinc and copper added to mineral soils. Environmental Pollution 107: 153-158.

MILLER GT (2000) Environmental effects of extracting and using mineral resources. In: editors Living in the Environment: 350-358. Brooks Cole Publishing Company, Pacific Grove, California, USA.

NEUMAN D, J SCHRACK \& L GOUGH (1987) Copper and molybdenum. In: Dean Williams and Gerald E. Schuman (eds.) Reclaiming mine soils and overburden in the western United States: 215-232. Soil Conservation Society of America Publishers, Ankeny, Iowa, USA

NORMAN D \& RL RAFORTH (1998) Innovations and trends in reclamation of metal-mine tailings in Washington. Geology 26: 29-42.

OLSEN SR \& LE SOMMERS (1982) Phosphorus. In: Page, Miller \& Keeney (eds) Methods of soil analysis: part 2. Chemical and microbiological properties: 403-430. American Society of Agronomy, Madison, Wisconsin, USA

PÉREZ V (2006) Estudio Inversión en la minería chilena del cobre y del oro. Proyección del período 2006 2010 actualizada a agosto 2006. Registro de Propiedad Intelectual (C) $\mathrm{N}^{\circ}$ 157.591. Comisión Chilena del Cobre Cochilco 29 pp.

POLLARD A, K DANDRIDGE, F HARPER \& J SMITH (2002) The genetic basis of metal hyperaccumulation in plants. Critical Review on Plant Sciences 21: 539-566.

RAJAKARUNA N (2004) The edaphic factor in the origin of plant species. International Geology Review 46: 471-478.

REEVES R \& A BAKER (2000) Metal-accumulating plants. In: Raskin I \& B Ensley (eds) Phytoremediation of toxic metals: using plants to clean the environment: 12: 193-229. John Wiley \& Sons, Inc. Hoboken, New Jersey, USA

RHOADS FM, SM OLSON \& A MANNING (1989) Copper toxicity in tomato plants. Journal of Environmental Quality 18: 195-197.

RÖMKENS PF, LA BOUWMANA \& GT BOONB (1999) Effect of plant growth on copper solubility and speciation in soil solution samples. Environmental Pollution 106: 315-321

SERNAGEOMIN (2003) Guía de buenas prácticas ambientales para la pequeña minería. Registro de Propiedad Intelectual $N^{\circ} 134.326$ ISBN 956-803803-5. pp. 8.

SMITH MR, I CHARVAT \& RL JACOBSON (1998) Arbuscular mycorrhizae promote establishment of prairie species in a tallgrass prairie restoration. Canadian Journal Botany 76: 1947-1954.

SONG J, ZHAO FJ, LUO YM, MCGRATH SP \& H ZHANG (2004) Copper uptake by Elsholtzia splendens and Silene vulgaris and assessment of copper phytoavailability in contaminated soils. Environmental Pollution 128: 307-315. 
TORREY JG \& RH BERG (1988) Some morphological features for generic characterization among the Casuarinaceae. American Journal of Botany 75: 864-874.

UNITED STATES ENVIRONMENTAL PROTECTION

Associate Editor: Rosanna Ginocchio

Received December 15, 2007; accepted May 29, 2008
AGENCY (1996) Method 3052: Microwave assisted acid digestion of siliceous and organically based matrices. Washington, District of Columbia, USA. 20 pp. 